\title{
Um olho muito além do lance
}

A glance well beyond the play

Un ojo mucho más allá de la jugada

\section{entrevista \\ Juca Kfouri}

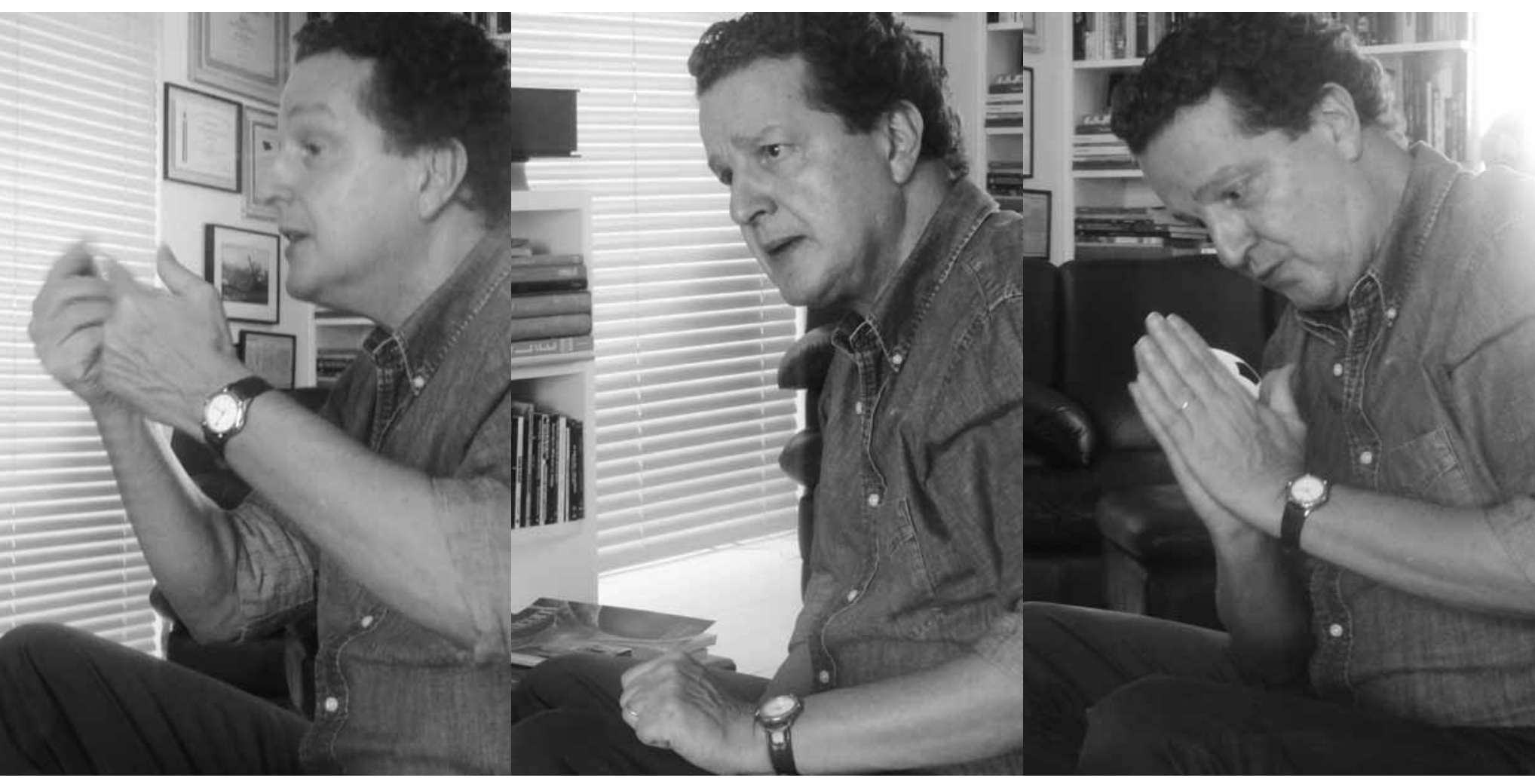


$D^{2}$ a varanda de um edifício na região de Higienópolis, podiam-se ver um dos grandes símbolos de São Paulo associado à consolidação do futebol no país e à reunião das paixões por esse esporte: uma praça onde ocorrem diversos shows e que, por vezes, cede lugar a grandes e calorosos debates políticos sobre a sua gestão e sua função - o Estádio Municipal Paulo Machado de Carvalho, o popular Estádio do Pacaembu. Nosso anfitrião não poderia ser pessoa mais ligada a esse monumento - não nos referimos ao estádio, não, ma ao monumento que é o futebol, uma das maiores expressões de brasilidade. Com seu largo sorriso e sua presença magnética, o sociólogo - ainda que poucos assim o associem - e jornalista Juca Kfouri nos recebe pronto a, com em gestos largos e palavras firmes, abrir a sua agenda e discutir conosco, de maneira franca, o esporte e a comunicação em nosso país.

$$
\star \star \star
$$

Organicom - Das ciências sociais ao futebol... Como um sociólogo acabou caindo no esporte?

Juca Kfouri - Na verdade, existe uma pergunta anterior a essa: como é que caí no jornalismo? Quando fui fazer ciências sociais, minha intenção era seguir a vida acadêmica. Entrei na faculdade na década de 1970 , no auge do governo Médici. Tinha como projeto, não sei se de dissertação de mestrado ou tese de doutoramento, fazer um trabalho sobre o futebol como fator de mobilização e não como fator de ordenação. Lembro-me de um episódio em que o querido professor Gabriel Cohn marcou uma prova para a noite de uma quar- ta-feira na qual jogavam Brasil e Romênia, na Copa do Mundo de 1970, no México. Eu levantei a mão: "Mas, professor, tem Brasil e Romênia!”. A minha classe me vaiou. O professor disse para levarmos a questão à discussão e para votarmos: quem queria manter e quem não queria manter a prova. Deu 20 a 1 pela manutenção da prova!". Porque, na época, se dizia "que cada gol do Brasil atrasava a revolução socialista brasileira, o fim da ditadura". Era a confusão que havia no seio da esquerda, de que a ditadura era dona de tudo, de que ela era dona da sua emoção. Discuti com meus colegas: "Quer dizer que eu não posso me emocionar com um jogo do Brasil? Vocês estão permitindo que a ditadura, que usurpou o poder no país usurpe também os seus sentimentos? Sou louco por futebol e vou torcer para o Brasil ganhar a copa do mundo e confirmo ao povo brasileiro que ele não vai confundir o Tostão ou o Pelé com o Médici”. Então saí da classe. Foi a única vez que eu vi aquele meu professor bravo, irritado. Falei para ele: "Professor, não venho fazer a prova, vou ver o jogo". Ele disse: "Tudo bem! Você vem na sexta-feira e faz a prova sozinho numa classe". Era junho de 1970. Passam-se doze anos e começa o governo Franco Montoro. O então diretor do Arquivo do Estado era o Prof. José Sebastião Witter, da Escola de Altos Estudos da Universidade de São Paulo, amigo meu. Ele me telefona, convidando-me para ir a uma reunião de um grupo que estava pensando em fazer uma enciclopédia do futebol brasileiro. Eu fui. Estou lá na reunião e... quem entra? Aquele meu professor de ciências sociais. Fazia anos que eu não o via. 
Saudei-o: "Mestre, que prazer em vê-lo, que surpresa!”. E ele respondeu: "Surpreso?". E me xingou:"Você é tão preconceituoso quanto seus colegas que me impediram de ver Brasil e Romênia na Copa de 1970!”. Eu falei: "Pô, professor! Você está de brincadeira? Foi você que marcou a prova, não fui eu!”. E ele: “Sim, é verdade, porque eu sou uma pessoa desligada, você bem sabe, esqueci que haveria jogo, senão não teria marcado a prova!”. E, depois de reclamar sobre o fato de eu nunca ter conversado com ele sobre futebol, lançou a máxima: "Não acredito em sociólogo no Brasil que não tenha os fundilhos das calças poluídos pelas arquibancadas”.

Organicom - E como foi parar nas redações?

Juca Kfouri - Fazia sociologia e aparece um convite para trabalhar na Editora Abril, com um belíssimo salário. A Abril tem essa marca inquestionável, de ter sido a primeira empresa jornalística brasileira a permitir que seus jornalistas tivessem um só emprego. Eu era moleque de vinte anos, namorava desde os quinze, queria me casar para ter o meu "aparelho", porque morria de medo de ser preso na casa dos meus pais. Meu pai era procurador de justiça, eu tinha mais três irmãos, e não queria colocar a minha família em risco permanente. Aí eu tinha dois problemas: um era me livrar do Curso Preparatório de Oficiais da Reserva (CPOR). Comecei então a trabalhar em uma área de apoio à revista Placar, no Departamento de Documentação e Pesquisa da Editora Abril (DDOC), concomitantemente com a faculdade. Quando acabei a faculdade, já era gerente do DDOC e fui convidado a chefiar a reportagem da Placar. Estava começando a pós-graduação, na área de política. Como vocês bem sabem, numa universidade pública, num país "sem problemas sociais" como o Brasil, pós-graduação só durante o dia, pois a universidade queria dedicação exclusiva. Mas a Editora Abril tinha como política pagar para seus funcionários, se quisessem fazer cursos de extensão universitária ou, no meu caso, como estava em universidade pública, liberaram as terças-feiras. Então terça-feira era o dia da minha vida, pois, em vez de ir à Abril, passava o dia na USP. E o que era o DDOC? Era o centro de documentação e pesquisa composto por gente da filosofia, da geografia, da história, de letras, das ciências sociais. Era um antro uspiano. Mas, como eu dizia, surgiu o convite para ser chefe de reportagem da Placar. E, para aceitar o convite, teria que largar a faculdade, porque a Placar fechava no domingo de madrugada, segunda-feira era dia de folga e terça-feira era o dia de abertura da revista. Quem abre a revista? O chefe de reportagem! Então, não seria possível compatibilizar essa atividade com a USP. E aí me dei conta de que estava contaminado por esse vírus do jornalismo. Então larguei a faculdade. Não continuei a pós-graduação, nunca escrevi a tal tese e, agora, procuro fazer no jornalismo esportivo algo mais abrangente do que meramente o jogo de futebol. Eu digo sempre o seguinte: "Não sei se o país ganhou um grande jornalista, mas perdeu um péssimo sociólogo...”.

Organicom - Poderíamos começar a conversa falando sobre o cenário do esporte no nosso país... 
Juca Kfouri - Acho o cenário do esporte brasileiro muito pobre para o tamanho da competência e do talento que têm os nossos esportistas. Começo dizendo que, quando falamos de esporte no Brasil, temos que ter muita clareza sobre o fato de que ainda não existe - 511 anos depois do Descobrimento - uma política esportiva no país. O Brasil não sabe o que quer ser quando crescer em matéria de esporte. E, frequentemente, como vemos agora por causa da Olimpíada no Rio de Janeiro, há uma enorme confusão sobre qual deve ser o papel do estado no fomento ao esporte. Está na Constituição que é seu papel prover ao cidadão a prática esportiva... É direito do cidadão a prática esportiva. Isso deveria ser entendido, evidentemente, como um esforço no sentido da democratização do acesso à prática esportiva, à massificação do esporte - para usarmos uma palavra mais simples -, e não como o modelo distorcido que o Brasil requer: que façamos medalhistas olímpicos. E isso, no Brasil, não só é "colocar o carro na frente dos bois" como, em regra, é fruto de acidentes de geração espontânea. Tirando as coisas que acontecem no futebol e, mais recentemente, no vôlei, os quais têm uma política que pode ser discutida - inteiramente voltada para as seleções, com pouco espaço para os clubes, e que têm uma sistemática geradora de campeões, todos os demais esportes brasileiros, em regra, possuem campeões que são frutos do acaso. Por exemplo, o Guga: qual é política que há no tênis brasileiro que revele "um Guga"? E por aí afora.

Organicom - E onde está a questão central?
Juca Kfouri - Está no fato de que se deve massificar, além de pensar no Brasil como um país com todas as suas dificuldades e no esporte como fator de saúde pública (existe um dado da Organização Mundial da Saúde, que diz que cada dólar investido em massificação de esporte poupa três dólares em saúde pública). Eu brinco sempre que o Ministério da Saúde no Brasil é o Ministério da Doença, que corre atrás de leitos de hospital etc. O Ministério da Saúde deveria ser o Ministério do Esporte, como prevenção. Mas isso passa ao largo das preocupações, da nossa supraestrutura esportiva e dos nossos governos que se sucedem ao longo dos tempos. Curiosamente, o esporte está nas mãos do PCdoB, com o qual poderíamos imaginar que existiria uma preocupação social, mas não há, infelizmente. $\mathrm{E}$ ainda há todos os outros absurdos: em um país com o tamanho e a população do Brasil, se o esporte fosse massificado, naturalmente aumentaria a quantidade e dela se extrairia a qualidade, pois aí passaria a ser uma atividade e atribuição da iniciativa privada, dos conceitos de excelência e da criação de grandes ídolos. Não que seja ruim termos ídolos esportivos, pois de certa maneira eles

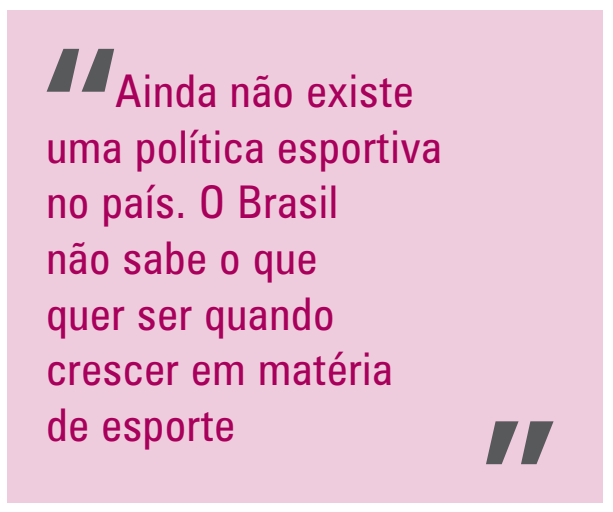


incentivam as pessoas a praticarem esportes e funcionam como exemplos. Mas não podemos inverter a situação: quando se ouve dizer que há uma preocupação do Comitê Olímpico Brasileiro (COB) de investir naqueles esportes que, eventualmente, tragam medalhas na Olimpíada do Rio de Janeiro, os investimentos caem em modalidades que não têm nada a ver com a nossa cultura esportiva. Houve uma olimpíada (acho que em Los Angeles) na qual o Brasil ficou na frente da Grã-Bretanha. Foi uma festa! Eu me lembro de ter participado de uma cerimônia, que era exatamente para comemorar essa façanha, na qual perguntei às pessoas (fui o estraga-prazeres da festa!): "Alguém aqui, neste recinto, supõe que o Brasil seja um país que pratique mais esporte do que os países que compõem a Grã-Bretanha? Há alguém aqui que imagine que em um parque brasileiro se encontre $\mathrm{o}$ que se encontra em Londres ou em Glasgow?” Evidentemente, naquela ocasião, houve algum problema lá na Grã-Bretanha. E não deu outra: demitiram o ministro do Esporte na Inglaterra, fizeram dois centros de excelência e nas olimpíadas seguintes a Inglaterra voltou ao sexto ou sétimo lugar, como de costume, e o Brasil ficou em décimo quinto. Mas o ponto é o seguinte: não me preocupo em ver o Brasil ganhando medalhas de ouro nas olimpíadas, mas me importa muito ver a juventude brasileira praticando esporte, a terceira idade brasileira fazendo esporte, o deficiente físico brasileiro tendo uma política que o apoie e que lhe permita fazer esporte. Essas devem ser as preocupações do estado brasileiro e do país como nação, mas não são. En- tão, a priori, nos falta uma política e, em relação àquilo em que temos um nível de excelência, padecemos das distorções vindas de um âmbito de poder no esporte que é mais do que uma supraestrutura conservadora. A supraestrutura esportiva brasileira é profundamente reacionária, avessa a qualquer tipo de mudança e profundamente corrupta e corruptora. Por exemplo, a Confederação Brasileira de Futebol, a conhecida CBF, tem um "coronel" há mais de vinte anos no poder, um poder baseado em capitanias hereditárias... Tendo sido estudante de ciências sociais, nunca tive coragem de dizer que o futebol brasileiro ainda vivia no período do feudalismo. A discussão sempre foi muito forte, nas ciências sociais brasileiras, em relação à predominância do sistema feudal ou do capitalista no país. E o futebol brasileiro vive essa contradição permanente.

Organicom - Você fala de gestão profissional?

Juca Kfouri - Se o futebol brasileiro fosse gerido de forma profissional, seria o equivalente ao que é a National Basketball Association (NBA) nos Estados Unidos, pela nossa produção inesgotável de talentos. Isso se tivéssemos o mínimo de organização. Mas o que temos são estádios vazios, com uma capacidade ociosa brutal e, mesmo assim, estamos construindo mais doze arenas para receber a Copa do Mundo de 2014, das quais certamente metade se tornará "elefantes brancos", assim como boa parte dos estádios feitos pela Ditadura Militar para "integrar" o Brasil pelo futebol. Então, nós temos muito a caminhar nisso. Ainda estamos, infelizmente, na nossa pré-história esportiva. 
Organicom - Falando especificamente do futebol: você disse que temos um certo ranço de conservadorismo. Você não acha que a imprensa esportiva também é conservadora?

Juca Kfouri - Sem dúvida nenhuma. Mais do que conservadora, ela é promíscua, infelizmente. Pegando exemplos lá atrás: 95\% da imprensa esportiva brasileira foi absolutamente contra a experiência da "democracia corinthiana”. Dá para contar nos dedos os veículos ou os jornalistas que a apoiaram, porque aquilo era visto como uma quebra de padrão. Considerava-se um absurdo a possibilidade de os jogadores saírem do treino e irem tomar cerveja na torre do Parque São Jorge, na frente dos associados. "Burros" - como dizia o Sócrates -, que não se davam conta de que o jogador, quando saía do treino e ia para casa, tomava meia garrafa de cachaça, e quando estava na frente dos sócios tomava duas ou três cervejas e ia embora, para não fazer vexame. Mas, enfim, se considerarmos que a maior parte da nossa população se informa pela televisão, a tevê aberta brasileira, no que diz respeito ao esporte, é sócia dessa gente e por isso não a denuncia, o que é um absurdo. Eu digo isso: o jornalismo esportivo da televisão é chapa-branca, mais do que o político, o que é curioso. Qual é o preço que a Rede Globo pagou durante todo o tempo da ditadura? A "tevê da ditadura", a "tevê que faz jornalismo chapa-branca", que "não enfrenta nada”... Hoje em dia, o jornalismo político da Rede Globo é extremamente crítico e há até quem o chame de golpista. Eu sempre sou a favor do jornalismo crítico, em relação a qualquer governo. Como dizia
Millôr Fernandes: "Jornalismo é oposição e o resto é armazém de secos e molhados". Mas o jornalismo esportivo é absolutamente subserviente. É feito pelos ditames de poucas pessoas por causa dos eventos que estas promovem. É uma lástima!

Organicom - E é extremamente significativo quando essa emissora tem um prêmio interno, de melhor jornalista, e dá esse prêmio para um camarada como o Tiago Leifert, que, com todo o respeito que merece, não é um jornalista na acepção da palavra. E é uma ofensa aos grandes jornalistas da casa.

Juca Kfouri - Sim, sem dúvida nenhuma. Mas é a tal história...Poderia haver ofensa maior do que a do Ricardo Teixeira na entrevista à revista Piauí? Um desrespeito maior aos jornalistas da casa? Dizer que a Globo só combina entrevista; que só se preocupa com o que vai sair no "Jornal Nacional”; que não sai nada que seja contra ele; que, quando saiu, ele pôs o jogo da Argentina em cima da novela e arrebentou a grade da Globo... Imagine! O cara já está insatisfeito lá dentro, incomodado com o fato de que se "acomodam" as coisas para essa pessoa. E essa mesma pessoa desrespeita todo mundo!

Organicom - E o que você acha dos modelos de jornalismo esportivo fora do Brasil?

Juca Kfouri - Vejamos um grande evento em uma rede norte-americana: o narrador, o comentarista e, invariavelmente, o repórter são todos ex-atletas daquele esporte. Estamos falando do departamento de entretenimento da ABC, da NBC, estamos falando de show. Acabou o show, entra o jornal 
com outra equipe, dessa vez de jornalistas, que mostram o que deu certo, o que deu errado no evento, por que deu errado etc. e fazem a cobertura, não importando se o evento é deles próprios ou não. Quando compro o carro de alguém, não viro seu sócio. Adquiri o carro e vou usá-lo. Se ele der problema, direi que está ruim e que o vendedor me passou um carro ruim - e... ponto! Da mesma forma, se compro um evento, apesar de dourá-lo para dar audiência, a transmissão deve ser feita separadamente do jornalismo por pessoas relacionadas ao esporte e por jornalistas.

Organicom - Existem muitas áreas no Brasil que trabalham com leis de incentivo, com o apoio do governo. Você acredita - voltando ao primeiro comentário - que isso poderia ser um caminho para fazer essa massificação, essa democratização do esporte?

Juca Kfouri - Não falta dinheiro para o esporte no Brasil e nem equipamento. Porque aí seria um assunto maior do que eu. É a discussão que sempre travo com o pessoal da educação física. Se formos olhar o que há de ginásios esportivos fechados, com goteiras, que políticos mandaram construir pelo Brasil afora, ficaremos estupefatos. Como vamos ficar estupefatos com a falta de quadras nas escolas municipais e estaduais... Falo de uma simples quadra! Em minha opinião, o desafio que está posto, para os nossos profissionais de educação física e para uma política esportiva é que não estamos em condições de fazer o ideal, mas de fazer o possível. E o possível é o seguinte: como estado, incentivo que os alunos das escolas de educação física, ganhando ponto
$\boldsymbol{U}_{\text {Não falta dinheiro }}$ e nem equipamento. Espaço para atividades esportivas nós temos. 0 que não temos é uma política que incentive a prática

em suas notas e matérias, dediquem dois finais de semana por mês a ir a determinada região carente de suas cidades para promoverem recreação. Recreação é pular amarelinha, dançar, esticar uma corda entre dois postes e improvisar um jogo de voleibol, pregar uma cesta na parede e jogar basquete. Cuba não é muito diferente disso. E, para deixar bem claro, não estou falando de criar uma potência esportiva para fazer propaganda política. Vejam-se os equipamentos cubanos... O que estou falando, em última análise, é que até hoje não nos demos conta de que, nos fins de semana, os bancos fecham e seus estacionamentos ficam sem nenhum automóvel. São espaços enormes onde se poderiam promover práticas recreativas e esportivas para uma população. Não nos demos conta de que as nossas escolas e os nossos quartéis fecham no fim de semana. Espaço nós temos, lugar para praticar atividades esportivas nós temos. O que não temos é uma política que incentive a prática. Para que se faça isso, nem é necessário muito dinheiro. Basta vontade política, dar o exemplo. Precisamos, eventualmente, de parcerias com a iniciativa privada. Por exemplo, uma possível proposta aos supermerca- 
dos: que, aos sábados e domingos, eles levem lanches, sucos, sanduíches e frutas para as pessoas que estiverem praticando esporte na periferia, permitindo-se que eles coloquem suas faixas e seus anúncios durante todo o fim de semana naquela região. Coisas simples assim. Temos todo um exército que ainda padece de uma imagem antipática, fruto dos anos de ditadura. Antes existisse uma política simpática, que possibilitasse a eventual abertura dos quartéis para a população! Mas, não. Temos uma postura tão absolutamente fechada e refratária a esse tipo de coisa que, como todos podemos testemunhar, já se chegou a fechar a Cidade Universitária de São Paulo, sob o pretexto de que a população a depredaria. Mas é a população que paga a Cidade Universitária. Estão quebrando? Fiscalize, eduque, ensine, não deixe quebrar. Fechar não é a solução, é a paz dos cemitérios. Daqui a pouco, como vemos, vai pegar no Brasil a ideia do jogo de futebol com uma torcida só. O passo seguinte será o jogo de futebol sem torcida. E não haverá mais "lado errado". Proíbo a torcida e não haverá mais briga. Porque somos incapazes, como fizeram a Inglaterra e outros países, de prevenir, de reprimir e de punir no caso de haver a violência. É isso!

Organicom - E sobre os megaeventos - a Copa do Mundo de 2014 e a Olimpiada de 2016: você acha que isso é bom para o pais? É oportunidade ou é armadilha?

Juca Kfouri - Em primeiro lugar, acho que são duas coisas diferentes. Vou começar pelo que, para mim, não faz sentido. Não faz sentido nenhum um país sem nenhuma tradição olímpica, sem nenhuma educação esportiva, promover uma olimpíada. Mais ainda quando sei que as mesmas pessoas que organizaram os Jogos Pan-Americanos de 2007, no Rio de Janeiro, vão organizar a Olimpíada de 2016. Os pan-americanos que iriam custar 380 milhões de reais em dinheiro público e custaram 4 bilhões... Os pan-americanos que iriam despoluir a Lagoa Rodrigo de Freitas e a Baía de Guanabara, que fariam a linha de metrô Jacarepaguá-Galeão... e não proporcionaram nada disso. Que levaram a construir o Engenhão, agora nem sequer cogitado para a Copa do Mundo de 2014 - embora seja o campo de futebol mais moderno do país. Que fizeram com que se montasse o Conjunto Aquático Maria Lenk sob a justificativa de estarmos fazendo uma estrutura suntuosa para os esses jogos - que, como sabemos, são de segunda categoria -, e, caso o Rio de Janeiro viesse a sediar a Olimpíada de 2016, ela já estaria pronta. Aí, quando o Rio de Janeiro é escolhido para organizar a olimpíada, o Comitê Olímpico Internacional (COI) julga o conjunto inapropriado, porque sua capacidade de público está aquém do que as provas de natação exigem. Então, o Maria Lenk vai ser servir ao aquecimento das provas de natação, ao polo aquático e aos saltos ornamentais, para não se ter que construir outro conjunto. São as mesmas pessoas que estão organizando a olimpíada. Pela primeira vez na história de mais de cem anos desses jogos, o presidente do comitê organizador é o mesmo do Comitê Olímpico Brasileiro (COB). Agora, me deem um nome dos membros do comitê organizador que o Brasil respeite. Não sobressai nenhum nome 
Não é hora de

o Brasil organizar

uma olimpíada.

É hora de ele tentar

começar a formar

uma cultura olímpica.

Estamos longe disso

de respeito. Não há, digamos assim, um Gerdau, não há um Ermírio de Moraes, não há um presidente da Ordem dos Advogados do Brasil (OAB), não há um cardeal do Rio de Janeiro, não há ninguém do qual se possa dizer "esse aí não põe a mão em cumbuca!". Então, minha posição em relação à Olimpíada de 2016 é essa: não é hora de o Brasil organizar uma olimpíada, é hora de ele tentar começar a formar uma cultura olímpica. Estamos longe disso...

Organicom - E quanto à Copa do Mundo de Futebol de 2014?

Juca Kfouri - É óbvio que o Brasil pode organizar uma copa do mundo. É o país mais vezes campeão do mundo, é um dos "países do futebol". A África do Sul acabou de fazer uma copa. Se ela pôde, por que o Brasil não poderia? No entanto, o Brasil pode e deveria fazer a Copa do Mundo do Brasil no Brasil, não a Copa do Mundo da Alemanha no Brasil ou a Copa do Mundo da Ásia no Brasil. Nós estamos indo nessa direção! Não preciso nem falar do absurdo que é fazer um estádio em Cuiabá, onde nem futebol profissional há; em fazer um estádio em Manaus, que não tem nenhum time na primeira, segunda ou terceira divisões nacionais; de fazer um estádio em Natal; de fazer um estádio no Recife, onde há três estádios, dos três clubes locais; de fazer um estádio para 70 mil pessoas em Brasília, para receber... o Brasiliense e o Gama! Vou falar, do meu ponto de vista, do maior escárnio que é o que está mais perto de mim: de se dizer que um estádio como o do Morumbi não pode receber, em um evento de um mês, sete jogos, quando ele está há cinquenta anos recebendo o futebol do mundo. Já foi palco de decisões da Copa Libertadores da América, do São Paulo, do Palmeiras, do Santos, já foi palco do primeiro Mundial de Clubes da Fifa, já foi palco das eliminatórias sul-americanas da Copa do Mundo. Mas, o Morumbi é o ideal? Não, não é o ideal, mas nós não podemos fazer o ideal. O ideal fizeram os alemães. Tinham lá um belo estádio, puseram no chão e fizeram o Allianz Arena de Munique, que é um espetáculo! Mas os alemães podem. Nós teríamos que reformar e adaptar o Morumbi, tratar das nossas estradas, do parque hoteleiro, da rede hospitalar, e não de fazer mais um estádio, como estamos fazendo em Itaquera, numa cidade como São Paulo, que tem o Pacaembu, tem o Morumbi, vai ter a Arena do Palmeiras. Claro que o Itaquerão não vai ser um elefante branco porque é o estádio do Corinthians. Que o Corinthians construa seu estádio, mas não com o nosso dinheiro! E é isso que está acontecendo. Aí alguém diz: "É legal, porque vai levar o progresso à zona leste". Convido vocês a fazerem o que eu fiz: vão ver se o Soccer City, onde se realizou o jogo inaugural da Copa Mundial de 2010, trouxe o pro- 
gresso ao Soweto! O Soccer City não trouxe o progresso ao Soweto - até porque no Soweto já existia o Ellis Park, que nunca foi fator de progresso, mas era um estádio que poderia perfeitamente ter recebido a copa, sem o Soccer City. Além disso, o Ellis Park era um estádio histórico, por todas as questões que conhecemos do Mandela, da final do rúgbi e tal. Mas vamos ao Engenhão e vejamos se ele levou progresso ao Engenho de Dentro: não levou! A Cidade do Cabo, que é uma das cidades mais lindas que eu já vi na vida, fez um estádio de futebol ecológico absolutamente deslumbrante, mas deverá ser implodido nos próximos meses porque está ocioso desde que acabou a Copa da África do Sul. No entanto, eles desalojaram quatro mil famílias que moravam na região e as puseram, provisoriamente, no que foi chamado de "cidade de lata", formada por uns quatro quilômetros de contêineres numa cidade com $45^{\circ} \mathrm{C}$ no verão e $-5^{\circ} \mathrm{C}$ no inverno... $\mathrm{E}$ as famílias estão lá até hoje! Esse é o "progresso" dos novos estádios. Mas, voltemos às questões das pessoas - que, infelizmente têm que ser tratadas. $\mathrm{Na}$ França, o presidente do comitê organizador da copa do mundo foi o $\mathrm{Mi}$ chel Platini, na Alemanha foi o Franz Beckenbauer. Nenhum dos dois era presidente das associações nacionais de futebol desses dois países. Mas no Brasil o presidente do comitê organizador da copa do mundo é o mesmo da CBF... Costumo brincar, quando faço palestra, que isso certamente, acontece porque em nosso país não há nenhum grande jogador de futebol de nome internacional que possa "emprestar" sua imagem! Andei pensando no Jucilei, mas ele foi para a Rússia, e então desisti! Um absurdo você pensar algo assim. De novo pergunto: deem-me um nome no comitê organizador da copa do mundo que vocês respeitem. A diretora-executiva é a filha do Ricardo Teixeira, o diretor-jurídico é o advogado pessoal do Ricardo Teixeira, o diretor de comunicação é o mesmo da CBF. Encampou!

Organicom - Gostaríamos de focar a questão da gestão, especificamente. Hoje, começamos a perceber que há uma tendência para sair um pouco daquele conceito de puro e simples empresário - o cara que vai lá, o primo, o irmão, que cuida da assinatura e tal e passa a ter uma gestão de carreira. Como você vê essa gestão de carreira e a eventual construção de imagem?

Juca Kfouri - É muito incipiente. No Brasil, ainda está se fazendo isso na base da tentativa-e-erro e às vezes com grupos de mecenas - que não são lá tão mecenas, mas montadores de fundos de investimento para ter jogadores, depois revendê-los e ganhar dinheiro. Isso não é necessariamente ruim. No entanto, desafio vocês a encontrar um clube de futebol no Brasil que tenha, por exemplo, um departamento de recursos humanos. Até hoje não existe. Vemos os jogadores ganharem fortunas $e$ não vemos clubes dispostos a pagar um salário razoável para um profissional especializado em psicologia do esporte, por exemplo. Vemos também, muitas vezes, esses garotos que vão ganhar fortunas perderem o rumo, porque lhes falta exatamente um respaldo psicológico para segurar a mudança que aconteceu na vida deles do dia para a noite. Eram favelados ontem e hoje têm a Merce- 
des-Benz do ano. Passava fome anteontem e hoje ganham 500 mil reais por mês. E é incrível que sejam raros os clubes com esse tipo de preocupação, que acreditem nisso, que é possível terem profissionais daquele tipo e que isso geraria uma rentabilidade interessantíssima para os clubes. Então, estamos ainda na idade da pedra nesse campo, porque existem mil hipocrisias: o presidente do clube não pode ser assalariado, tem que ser abnegado! De duas, uma: ou é multibilionário ou vai ficar. $\mathrm{E}$ a regra é que vai ficar.

Organicom - Essa tendência que tem se mostrado de forma incipiente, de profissionalização da gestão do esporte no Brasil - veja-se Rosenberg, um exemplo muito interessante, Júlio Casares... Você acha que essa deva ser a tendência para ofuturo?

Juca Kfouri - Nenhum dos citados é remunerado. São apaixonados, não profissionais, e que estão em um estágio da sua vida que lhes permite dedicar uma parte do seu tempo para essa sua paixão. Ótimo! O que eu acho que existe de novo, felizmente, se o Brasil precisar, é uma garotada saindo das faculdades, especializada em direito esportivo, gestão de esporte, marketing esportivo, que está aí para ser usada. É mais ou menos essa a situação que se encontra na Europa: os clubes ainda são dominados por velhas figuras, mas o segundo escalão é todinho de um bando de profissionais da maior competência, que faz virar o que viraram os clubes ingleses ou o Campeonato Inglês de Futebol ou potências como o Barcelona, que explora as coisas da Catalunha. E eles têm essa dimensão sobre o que é o profissional, o bom profissional, o bom gestor de um clube de futebol: é aquele cara que, friamente, é capaz de exacerbar a paixão. Em semana em que o Corinthians é campeão, se vende papel preto e branco pintado! Mas deve-se saber fazer isso. Agora, não parece completamente absurdo constatar que clubes como o Corinthians e o Flamengo, com a massa que existe por trás deles, com as dívidas que eles têm, estarem sujeitos a uma má gestão? Por dinheiro que não se sabe para onde foi, por falta de transparência.

Organicom - E como você enxerga essa questão da legislação?

Juca Kfouri - Eu acho que deveríamos ter clubes-empresas ou departamentos de futebol. Quando digo clube-empresa, não significa que esteja sugerindo que a parte social se perca. Departamento de futebol profissional tem que ser regido por um código comercial e, como tal, será uma empresa e funcionará como uma empresa. E aí se acaba com a hipocrisia. É feito um contrato com a pessoa que irá dirigir isso - o presidente do Corinthians irá ganhar o que ganha o presidente das multinacionais $\mathrm{Ge}$ -

\section{$\triangle$ Há uma garotada saindo das faculdades, especializada em direito esportivo, gestão de esporte, marketing esportivo, que está aí para ser usada}


neral Motors ou Volkswagen do Brasil. Salário compatível e, se ganhar o Campeonato Brasileiro, a Libertadores, algum Mundial, vai ser bonificado. Tem que estar no papel! Isso tem muito a ver com a nossa tradição judaico-cristã. Parece que é feio ganhar dinheiro e, por isso, tratemos de ganhar por baixo do tapete, sem que ninguém veja. É diferente da filosofia anglo-saxônica: o norte-americano bota na capa da Time o garoto que fez 1 milhão de dólares com vinte anos de idade; aqui diriam que, por trás disso, há alguma falcatrua. Porque as coisas são feitas por baixo do pano.

Organicom - Já que você está falando para uma revista acadêmica, nos vem a seguinte questão: normalmente, quem faz mestrado ou doutorado e elege o esporte como seu tema central de pesquisa, é visto pela comunidade acadêmica como um pesquisador menor. Mas não existe, em nossa opinião, fenômeno cultural que explique melhor este pais do que o futebol. Você acha que esse certo preconceito tem a ver com a ditadura passada?

Juca Kfouri - Não acho que tenha a ver especialmente com a ditadura. Creio que as coisas melhoraram bastante: hoje, a produção intelectual em tor-

$$
\begin{aligned}
& \square \text { Já são inúmeras } \\
& \text { as publicações sobre } \\
& \text { futebol, sociologia do } \\
& \text { esporte, direito esportivo, } \\
& \text { biografias de jogadores } \\
& \text { etc. E coisas } \\
& \text { de muita qualidade }
\end{aligned}
$$

no do futebol é enorme. E cito aqui uma coisa. Quando comecei a trabalhar como jornalista, em 1970, existiam cinco ou seis livros ou textos com futebol como tema: o célebre $O$ negro no futebol brasileiro, do Mário Filho; o Almanaque esportivo olympicus, uma espécie de enciclopédia, de Tomaz Mazzoni; um artigo na revista Argumento, de um professor alemão; o romance $O$ sol e o escuro, de um escritor gaúcho; e nada mais. Agora são inúmeros os temas e as publicações sobre futebol, sociologia do esporte, direito esportivo, romance, literatura do esporte, os clubes, biografias de jogadores etc. E coisas de muita qualidade. Então, isso mudou muito. Agora, acho que, mais do que fruto da ditadura - do aproveitamento que a ditadura fez do tricampeonato de 1970, causando certos engulhos em certa área da nossa esquerda -, isso tem a ver com a tradição elitista, de cultura europeia, da nossa elite intelectual. Por exemplo, Fernando Henrique, "o professor", "o príncipe dos sociólogos": conversava-se sobre futebol com ele e percebia-se que ele captava, mas, na minha sensação, quando saía da sala, ele certamente falava algo assim: "O Juca enlouqueceu. Imagina! Eu tenho mais no que pensar do que em futebol!". Ele fez coisas ótimas, como o "Estatuto do torcedor", mas não entendia nada de futebol. O Lula, diferentemente, entendeu tudo. E é o que não perdoo nele, porque ele entendeu tudo e nos traiu ao se acumpliciar com o Ricardo Teixeira. Mas o Fernando Henrique achava que Biro-Biro era uma jogada de "bicicleta", não o apelido de um jogador do Corinthians. O carnaval também era visto como uma coisa menor. Como pode a área 
acadêmica desprezar duas das manifestações culturais mais arraigadas no povo brasileiro? Não gosto de carnaval, mas não é por isso que não vou respeitá-lo como uma manifestação cultural e entendo perfeitamente quando e como ele acontece. Então, acho que é muito mais por aí do que por causa da ditadura. Porque a ditadura, apesar de tudo, foi uma coisa episódica também.

Organicom - E também existe a célebre frase do Roberto DaMatta, sobre o "ópio do povo"...

Juca Kfouri - Pois é, mas na verdade é uma apropriação, porque antes era a religião o "ópio do povo". Eu acho isso um equívoco.

Organicom - Saindo um pouco da monocultura do futebol: a gente tem espaço para outros esportes?

Juca Kfouri - Acho que sim. Nós sabemos que brasileiro gosta de ganhar. O brasileiro ficou louco pelo Guga - todos eram apaixonados pelo tênis e entendiam desse esporte. O voleibol virou o que virou! Não tenhamos dúvidas: dez anos de vitórias no basquete e ele volta a ser o que era, pois nós gostamos muito mais de basquete do que de vôlei; tem muito mais a ver com a nossa alma o basquete que o vôlei. Mas o vôlei virou o que virou porque ganha. Automobilismo e fórmula 1 ... O país não se tornou "o país do automobilismo"? Nem considero o automobilismo um esporte, diga-se de passagem, mas de repente todos falavam da Lotus, da McLaren e de tudo o mais, com um conhecimento de causa espantoso. E um dia perguntaram ao Jackie Stewart o que explicava esses brasileiros campeões. Ele disse: "Não sei, deve ser a água que eles bebem". Mas eu acho que os outros esportes podem entrar em cena, nunca a ponto de competir com o futebol, mas podem. Agora, eu estava dando o exemplo da "não-massificação": demos uma olhada na equipe de remo do Brasil. Os remadores brasileiros são, em regra, daqui, da raia olímpica da USP, ou da Lagoa Rodrigo de Freitas no Rio de Janeiro. Não há um remador da região amazônica, onde crianças de cinco anos de idade, das populações ribeirinhas, vão para a escola remando. Já imaginamos o que existe de talento ali? O que há de gente que nasceu remando e que se pode pegar, em determinado momento da vida, para fazê-la florescer? O fato é que nós somos muito descuidados.

Organicom - Você acredita que o esporte, de uma forma geral, tem como fugir desse dominio dos grandes meios de comunicação de massa, da mídia, e deixar de ser só entretenimento?

Juca Kfouri - Sendo otimista, acredito que essas coisas caminharão, à medida que caminha a democracia brasileira e a consciência cidadã do brasileiro. É evidente que isso não pode ficar nas mãos de pouca gente, que isso é um patrimônio cultural de nosso povo e assim deve ser tratado. Antes falamos do olhar preconceituoso que existe em relação a quem estuda esporte. Quando comecei a ser jornalista, a brincadeira que se fazia era essa: o cara chegava à redação e perguntava: “Tem emprego aí?". "Emprego tem, mas o que você sabe fazer?". "Nada". Então ele ia para a seção de esporte ou de polícia. Isso 
também mudou nas redações. Acho que são passos que vão se dando. Um dia desses, escrevi um artigo, para a revista Interesse Nacional, uma publicação da elite intelectual. Vocês estão aqui, nós estamos falando de esporte, e cada vez mais a universidade é local desse tipo de debate, desse tipo de discussão. Mas acho que nós não percebemos, porque estamos tão envolvidos no dia a dia que não nos damos conta de como isso está proliferando pelo Brasil afora. Há um ano, fiz um circuito interessantíssimo: dez palestras no interior do Paraná e do Rio Grande do Sul, nos teatros dos colégios samaritanos. A palestra com menos gente reuniu 450 pessoas. Em Foz do Iguaçu, foram 850. E todos jovens. E não há mais a dizer, pelo menos no meu caso, que há anos saí da Rede Globo... Eu era um cara que falava desses troços chatos. Mas agora não vou lá contar a história do Pelé, do Garrincha ou do Zico e, sim, pôr o dedo na ferida. Mesmo assim, os salões estavam cheios de gente. Tenho certeza de que isso não é de graça e atende a uma reivindicação que está no ar. E, por mais que nos exasperemos, porque achamos que as coisas são lentas, isso vai frutificar, não tenho muitas dúvidas.

Organicom - Tomara!... Mas é dificil não ser pessimista. Por exemplo: Pelé é rei, Maradona é deus e Messi... é um jogador de Playstation...

Juca Kfouri - Mas vejam uma coisa: entrem no meu blog, por exemplo, e leiam os comentários, leiam o que há de "porrada", inclusive em mim, de gente que acha que estou simplificando, ou que estou me curvando à audiência. Há uma massa crítica presente. $\square$ Por mais que

nos exasperemos, porque achamos

que as coisas são

lentas, isso vai

frutificar, não tenho

muitas dúvidas

Hoje, quando se vai fazer uma palestra, somos muito mais inquiridos do que há quinze anos. As pessoas aceitam muito menos "pratos feitos" do que antes $A$ internet tem a grande qualidade de ter diminuído distâncias. Mas tem também uma porção de problemas: estimula a covardia, as pessoas não se identificam, sabem quem você é e você não sabe quem são eles, estimula a cafajestagem, a falta de educação. Ela tem tudo isso. Mas tem o lucro central, o lucro do debate, que é muito interessante.

Organicom - Voltando à velha questão da não-profissionalização no esporte... Assim como não temos psicólogos, percebemos que não há um trabalho de comunicação dos clubes, inclusive um trabalho de comunicação com a grande população, com os grandes públicos desses clubes. Talvez até haja um trabalho de disseminação da marca, em alguns casos pontuais. Você acha que isso poderia ser mais um caminho?

Juca Kfouri - Não tenho a menor dúvida! Não faz vinte anos, descobriu-se que os clubes não tinham suas marcas registradas no Instituto Nacional de Patentes. Havia alguém que detinha as marcas do Corinthians e do 
Palmeiras. E tiveram que denunciá-lo. Claro que na justiça ela perderia, mas, como as pessoas tinham certa pressa, ele ganhou um dinheiro dos clubes para abdicar de ser o dono dessas marcas. Claro que de lá para cá isso evoluiu, mas o problema de hoje é que os bons profissionais esbarram em uma coisa nebulosa que um bom profissional não quer viver. Não sei se alguém concorda, mas boa parte do nosso atraso nos esportes olímpicos eu associo ao fato de os nossos clubes tradicionais de futebol terem deixado de ter as suas equipes de basquete, de vôlei etc. Mas por que deixaram de tê-las? Porque custam caro. E os patrocinadores? É evidente que interessa muito mais para a Nestlé ter o time Corinthians-Nestlé de basquete ou de vôlei, do que ter o time "Leite Moça" de voleibol feminino. Porque ninguém vai ao Gi- násio do Ibirapuera para gritar "Leite Moça!" ou "Nestlé!" ou "Pirelli!" ou "Bradesco!". Isso não tem a ver com a nossa cultura. Tem até a ver com a cultura do Japão. Com a nossa é Flamengo, Vasco, Cruzeiro... Mas, como é que um banco pode negociar com essa gente e receber pedidos de dinheiro por fora e caixa-dois? Um dia perguntei a alguém do marketing do Banco do Brasil, na ocasião em que determinado banco lançou os cartões de crédito com a marca dos clubes - o que também não progrediu: "Como é que o Banco do Brasil perde um mercado desses? Ele tem tudo a ver com a seleção brasileira de futebol, com o Corinthians, com o Flamengo". E ele disse: "É, também acho, mas você já imaginou o Banco do Brasil com caixa-dois?”. Logo eles estarão fora e um aventureiro estará dentro. 